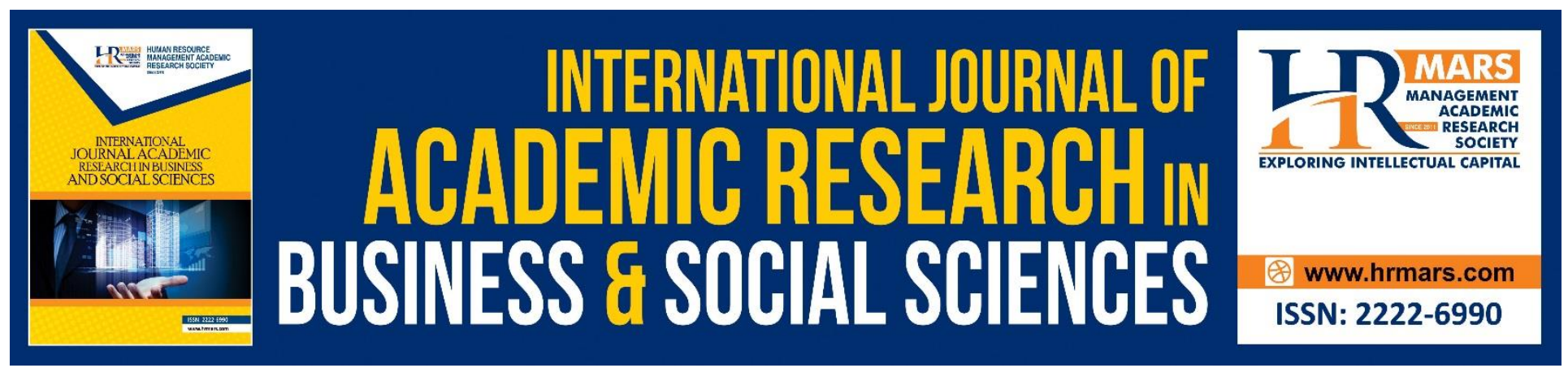

\title{
The Effect of Motivation on Performance at the Women's Cooperative Institute in Al - Barokah, Tuban Regency
}

\author{
Endang Muryani, Alvien Gunawan, Zamri Bin Chik, Dedi Iskamto, \\ Putra Budi Ansori
}

To Link this Article: http://dx.doi.org/10.6007/IJARBSS/v8-i12/5413

DOI: $10.6007 /$ IJARBSS/v8-i12/5413

Received: 13 Nov 2018, Revised: 19 Dec 2018, Accepted: 25 Dec 2018

Published Online: 10 Jan 2019

In-Text Citation: (Muryani, Gunawan, Chik, Iskamto, \& Ansori, 2018)

To Cite this Article: Muryani, E., Gunawan, A., Chik, Z. Bin, Iskamto, D., \& Ansori, P. B. (2018). The Effect of Motivation on Performance at the Women's Cooperative Institute in Al - Barokah, Tuban Regency.

International Journal of Academic Research in Business and Social Sciences, 8(12), 2136 - 2141.

Copyright: (C) 2018 The Author(s)

Published by Human Resource Management Academic Research Society (www.hrmars.com)

This article is published under the Creative Commons Attribution (CC BY 4.0) license. Anyone may reproduce, distribute, translate and create derivative works of this article (for both commercial and non-commercial purposes), subject to full attribution to the original publication and authors. The full terms of this license may be seen

at: http://creativecommons.org/licences/by/4.0/legalcode

\section{Vol. 8, No. 12, 2018, Pg. $2136-2141$}

Full Terms \& Conditions of access and use can be found at http://hrmars.com/index.php/pages/detail/publication-ethics 


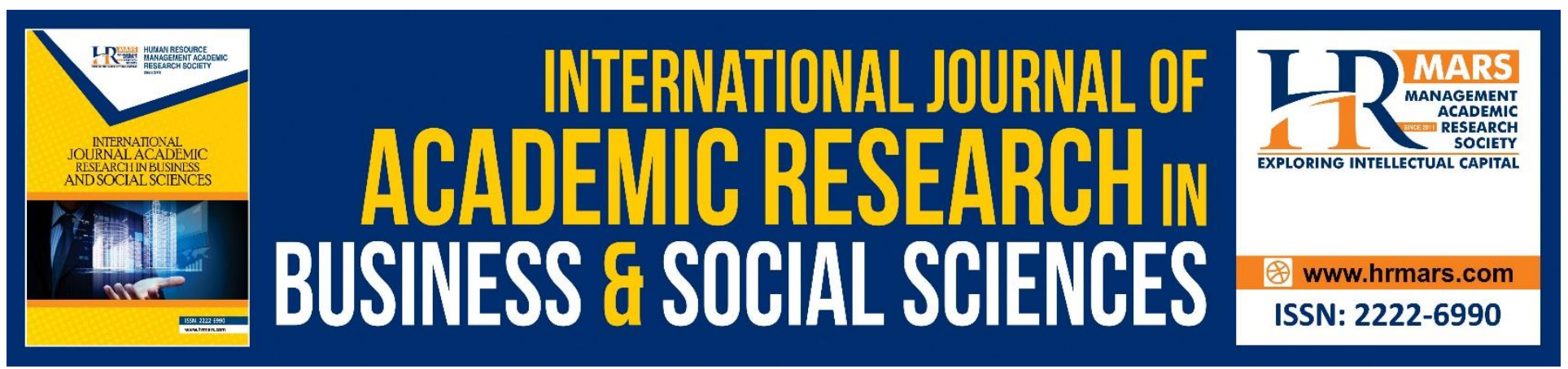

\title{
The Effect of Motivation on Performance at the Women's Cooperative Institute in Al - Barokah, Tuban Regency
}

\author{
Endang Muryani ${ }^{1}$, Alvien Gunawan², Zamri Bin Chik $^{3}$, Dedi Iskamto \\ Putra Budi Ansori ${ }^{5}$ \\ ${ }^{1}$ Lecturer of Universitas Merdeka Surabaya \\ ${ }^{2}$ Lecturer of Universitas Maarif Hasyim Latif \\ ${ }^{3}$ Faculty of Contemporary Islam, Universiti Sultan Zainal Abidin \\ 4, 5 Sekolah Tinggi Ilmu Ekonomi Riau.
}

\begin{abstract}
High motivation will improve one's performance at work. Work motivation can be realized when leadership in the organization goes well. It also motivates employees to work in accordance with the achievement of the desired goals. The purpose of this study was to determine the effect of motivation on employee performance at the Al-Barokah women's cooperative institution in Tuban Regency. In this study sampling technique was not used because the sample studied was the entire population or what was called the census. With the number of study samples totaling 584 people's, consisting of employees at the Al-Barokah women's cooperative institution in Tuban. The data in this study uses quantitative-based studies. Data were collected using Statistical Package for the Social Sciences (SPSS). The study shows that $96 \%$ of the motivation impression on employee performance at the AlBarokah women's cooperative institution in Tuban. This achievement shows that motivation plays a major role in improving the performance of existing employees in the Al-Barokah women's cooperative in Tuban Regency.
\end{abstract}

Keywords: Motivation, Performance, Women's Cooperative Institute

\section{INTRODUCTION}

Every government organization is required to be able to improve performance by optimizing the use of human resources and how human resources are managed. Management of human resources can not be separated from the factors of employees who are expected to perform as well as possible in order to achieve the goals of government organizations. Employees are the main assets of the organization and have a strategic role in the organization, namely as thinkers, planners and control of organizational activities. In order to achieve organizational goals, employees need motivation to 
work more diligently, so that their performance can be improved. With high work motivation, employees will work harder in carrying out their work. Conversely with low work motivation employees do not have the spirit of work, easily give up, and difficulties in completing their work.

In a general sense, motivation is said to be a necessity that drives action towards a particular goal. The term motivation comes from the Latin word "movere" which means encouragement or movement. Motivation questions how to direct power and the potential to work towards the goals set (Hasibuan, 2006). Basically a person works because of the desire to fulfill his life needs. Encouragement of desire in someone with another person is different so that human behavior tends to vary in work.

Motivation is a force or factor contained in a human being, which gives rise, directs and organizes his behavior. By doing work that becomes an impulse found in a person, so trying to make changes in behavior that is better in meeting their needs (Uno, 2008).

\section{Motivation Theory}

Motivation theory according to experts is divided into three, namely, the theory of needs about motivation, humanistic theory, and behavioristic theory (Prayitno, 1989).

1. Need Theory

This theory says that humans as beings who will not be satisfied only by fulfilling one need, but he will be satisfied if all needs are met. Even though all needs have been fulfilled, surely he will pursue new needs. So that these needs are met, then he will be motivated to achieve the desired needs. So that makes him satisfied, but satisfaction is only for a while. So on, until the highest needs are satisfied.

2. Humanistic Theory

This theory believes that there is only one motivation, namely motivation that only comes from each individual. The motivation is owned by the individual at all times and wherever he is. What's more important according to this theory is to respect or respect a person as a human being who has the potential and desire to learn.

3. Behavioristic Theory

This theory argues that motivation is controlled by the environment. A motivated behavior occurs when the consequences of behavior can vibrate an individual's emotions, which is to be like or dislike. If the consequences of behavior give rise to liking, then behavior becomes strong. But on the contrary, if the behavior causes dislike, then the behavior will be abandoned. 
INTERNATIONAL JOURNAL OF ACADEMIC RESEARCH IN BUSINESS AND SOCIAL SCIENCES

Vol. 8, No. 12, Dec, 2018, E-ISSN: 2222-6990 @ 2018 HRMARS

\section{Motivation Function}

According to Notoatmodjo (2007), motivation has three functions, namely:

1. Encourage humans to act as drivers or motors that release energy. Motivation in this case is the driving force of every activity that will be carried out.

2. Determine the direction of action, which is towards the goal to be achieved. Thus motivation can provide direction and activities that must be done in accordance with the formulation of the goals that have been planned in advance.

3. Selecting actions, namely determining what actions must be done in harmony to achieve the goal. So by setting aside actions that are not useful for that purpose. The choice of actions that have been determined or done will give high self-confidence because they have done a rigorous selection process.

\section{LITERATURE REVIEW}

The study of Arta (2015) which discusses the influence of motivation and work environment states that based on the results of SPSS calculations obtained the value of $a=-4.946$, the value of $b 1=0.669$ and the value of $\mathrm{b} 2=0.549$, the multiple linear regression equation becomes $Y=-4.946+0.669 \times 1+$ $0.549 \times 2$. Based on the results of this equation, it can be explained the pattern of influence of Motivation (X1) and Work Environment (X2) on Performance (Y), namely: A value of $-4,946$ means that if motivation and work environment do not change or equal to zero, then employee performance will decrease by $4,946 \%$. Value of b1 $=0.669$ means that if motivation (X1) increases by $1 \%$ and the work environment $(\mathrm{X} 2)$ remains, then performance $(Y)$ increases by $0.669 \%$. Value of b2 $=0.549$ means that if the work environment $(X 2)$ increases by $1 \%$ and motivation (X1) remains, then performance $(\mathrm{Y})$ increases by $0.549 \%$. Unstandardized Beta Coefficients $\mathrm{X} 1=0.669$ and $\mathrm{X} 2=0.549$ means that motivation (X1) is more dominant in influencing employee performance (Y) compared to the work environment $(\mathrm{X} 2)$.

Mawarni (2016) states that based on the results of regression calculations can be seen $t$ count $=$ $2.382>t$ table $=2.021$ with a significance value of 0.022 with an error rate (Alpha) 0.05 . From the test results it can be concluded that there is an influence of work motivation on the performance of financial employees. Besides the test results show that the Beta value is 0.252 , this shows that the direction of influence is positive, the higher the motivation the employee has, the better the employee's performance will be. Thus, the motivation possessed by employees can also support employees to carry out their duties and obligations properly and produce performance levels that are in line with organizational expectations.

Furthermore Sutrischastini (2015) also mentions in his study that the magnitude of the coefficient of determination is 0.962 which means that the effect of the independent variable on the change in the dependent variable is $96.2 \%$. While $3.8 \%$ is influenced by other variables. This means that performance is greatly influenced by work motivation (Incentive / X1, Motif/X2 and Hope/X3). Thus, it is evident that work motivation which consists of incentives, motives, and expectations has a 
INTERNATIONAL JOURNAL OF ACADEMIC RESEARCH IN BUSINESS AND SOCIAL SCIENCES

Vol. 8, No. 12, Dec, 2018, E-ISSN: $2222-6990$ C 2018 HRMARS

positive and significant effect on the performance of employees of the Regional Secretariat of Gunungkidul Regency.

\section{RESEARCH METHODOLOGY}

The research population is employees who are institutionalized by the Al-Barokah women's cooperative in Tuban Regency. This study uses a sampling technique because the sample under study is the entire population or the so-called census. With the number of study samples as full as 584 people's consisting of employees at the Al - Barokah women's cooperative institution in Tuban Regency.

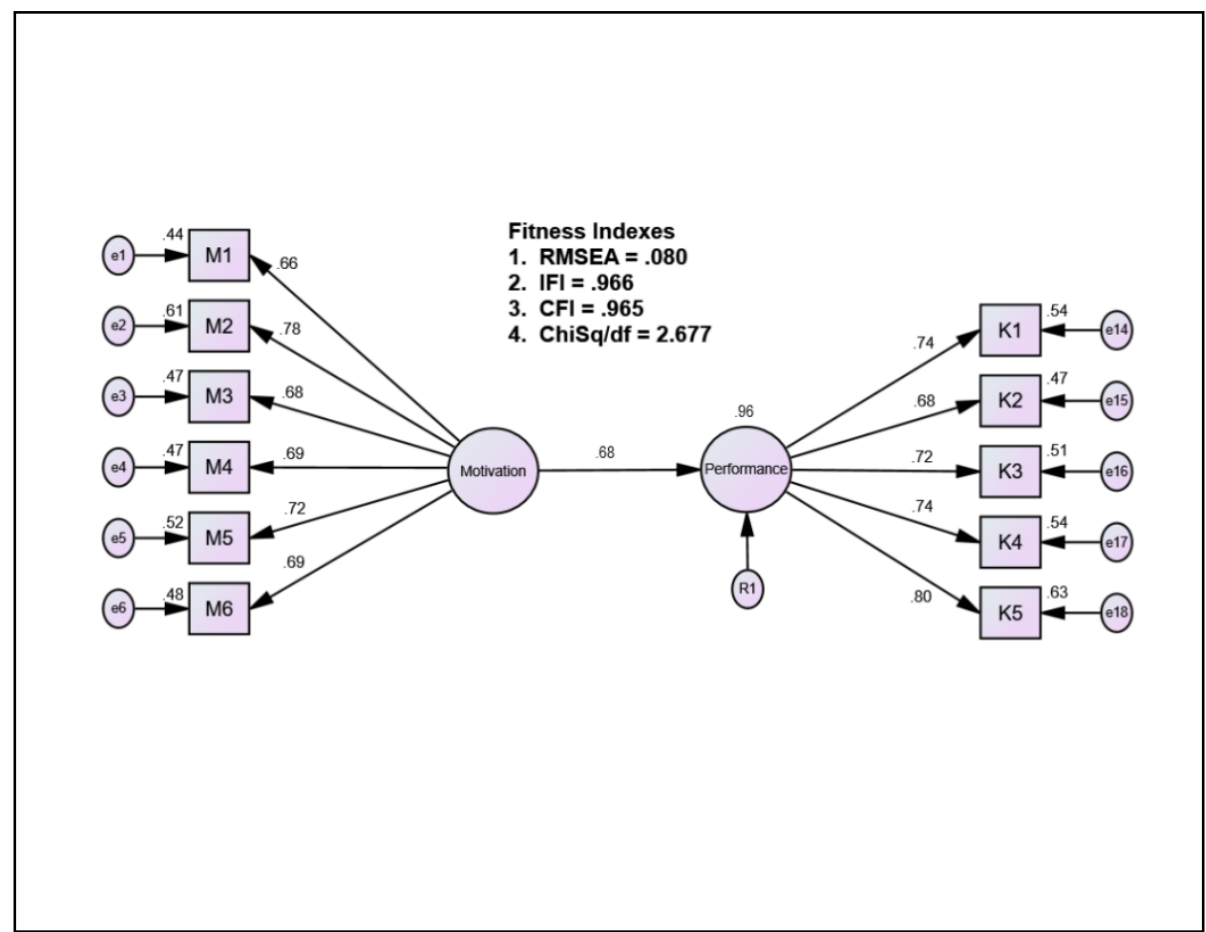

Figure 1: Model of Study-Items Questionnaire Following Construct Motivation \& Performance

\section{RESULTS AND DISCUSSION}

The study findings show that the motivation found in the employees of the Al-Barokah women's cooperative institution in Tuban District is very high at $96 \%(R 2=0.96)$. The findings of this study illustrate that motivation is the main factor influencing the work performance of employees in the Al-Barokah women's cooperative in Tuban Regency. This achievement shows that humanistic theory has manifested itself in employees institutionalized by the Al-Barokah women's cooperative in Tuban. This theory is a practice in the performance of employees so that it produces a very high motivation attitude. 
INTERNATIONAL JOURNAL OF ACADEMIC RESEARCH IN BUSINESS AND SOCIAL SCIENCES

Vol. 8, No. 12, Dec, 2018, E-ISSN: $2222-6990$ C 2018 HRMARS

\section{CONCLUSION}

Overall, motivation plays a major role in the performance of each employee at the Al-Barokah women's cooperative institution in Tuban Regency. This illustrates that motivation is a force or the main factor contained in a human being. So that it can generate and direct and organize its behavior.

\section{REFERENCES}

Sutrischastini, A. (2015). Pengaruh Motivasi Kerja Terhadap Kinerja Pegawai Kantor Sekretariat Daerah Kabupaten Gunungkidul. Jurnal Kajian Bisnis, Vol. 23, No. 2 Juli 2015.

Arta, D. P M. (2015). Pengaruh Motivasi dan Lingkungan Kerja Terhadap Kinerja Pegawai Negeri Sipil Pada Kantor Pengawasan dan Pelayanan Bea dan Cukai Tipe Madya Pabean Ngurah Rai Kabupaten Badung. Jurnal Juima, Vol. 5, No. 1 Maret 2015.

Hamzah, B. U. (2008). Teori Motivasi dan Pengukurannya Analisis di Bidang Pendidikan. Bumi Aksara : Jakarta

Hasibuan, M.S.P. (2006). Manajemen Dasar, Pengertian, dan Masalah. Edisi Revisi. Bumi Aksara: Jakarta.

Notoatmodjo, S. (2007). Promosi Kesehatan dan Ilmu Perilaku. Jakarta : Rineka Cipta.

Prayitno, E. (1989). Motivasi dalam Belajar dan Berprestasi. Departemen Pendidikan dan Kebudayaan Direktorat Jenderal Pendidikan Tinggi. Jakarta.

Mawarni, T. (2016). Pengaruh Motivasi Kerja, Kepuasan Kerja dan Kompensasi Terhadap Kinerja Pegawai Bagian Keuangan pada Pemerintah Daerah. Jurnal JOM Fekon, Vol. 3, No. 1 Februari 2016. 